\title{
Perspectives on permaculture for commercial farming: aspirations and realities
}

\author{
Immo Fiebrig $(\mathbb{D} \cdot$ Sabine Zikeli $\cdot$ Sonja Bach $\cdot$ \\ Sabine Gruber
}

Received: 31 October 2019 / Accepted: 10 January 2020 /Published online: 25 January 2020

(C) The Author(s) 2020

\begin{abstract}
The term 'Permaculture' (PC) refers to a theory about diversified farming systems, based on an ethical attitude (worldview) and a practical design process, guided by 12 principles and flanked by a holistic sustainability concept. Invented in the wake of Australia's socio-political 'back-to-the-land' aspirations of the 1970s, PC has since developed and grown into a diverse international grassroot movement. It can be considered a rural as well as an urban socio-cultural phenomenon that revolves around non-commercial gardening, for example urban community projects, or around farming for self-sufficiency, for instance in eco-villages. This paper intends to investigate which aspects of PC may be scalable to commercial farming whilst identifying PC aspects already implemented in commercial (organic) agriculture (OA). It analyses a current business case led by a German wholesaler of organic produce who worked in cooperation with a
\end{abstract}

\section{Fiebrig $(\bowtie)$}

NCMH, School of Biosciences, University of Nottingham, Sutton Bonington Campus, Sutton Bonington LE12 5RD, UK

e-mail: immo.fiebrig@nottingham.ac.uk

S. Zikeli

University of Hohenheim Centre for Organic Farming (309),

Fruwirthstr. 14, 70599 Stuttgart, Germany

S. Bach

Permakultur Institut e.V. Im Garten 11, Hoffnungsthal,

51503 Rosrath, Germany

\section{S. Gruber}

University of Hohenheim, Institute of Crop Science (340a),

Fruwirthstr. 23, 70599 Stuttgart, Germany
German supermarket chain to create the first nationwide PC label. To this end, the paper describes the degree of overlap between two organic farming certification schemes and the case study. As opposed to certified $\mathrm{OA}, \mathrm{PC}$ is less prescriptive, using a deductive and inductive approach instead. It may expand scope and flexibility required for farm redesign towards improved resilience, reaching out to the landscape level. The productiveness of PC in commercial settings needs to be established further, such as best practices in soil regeneration and monitoring as well as the reduction of soil losses, or the valuation of added ecosystem services such as promotion of (agro-)biodiversity.

Keywords Permaculture - Demeter certification . Ecosystem services

\section{Introduction}

Balancing the needs of an increasing world population with the demands of the world's biological diversity (Lal 2016; FAO, IFAD, UNICEF, WFP, WHO 2017) calls for profound changes to the way humans produce food at the primary level. Reversing anthropogenic environmental degradation - caused in particular by unsustainable land use practices - is a prerequisite for long-term human survival. Degraded or destroyed resources such as forests, natural habitats, fertile land, water, biodiversity or human livelihoods need to be restored to counteract the realities of climate change 
and not least as laid down by the UN Sustainable Development Goals (UN The General Assembly 2018).

While intergovernmental organisations can be pivotal in setting agendas that subsequently need to be implemented by national governments in a mostly top-down process, the current work reviews the achievements of a grassroot social movement and of farmers who identify themselves with 'permaculture' (PC), arguably the most comprehensive sustainability concept devised so far (Urwin and Jordan 2008). PC advocates not only for sustainable practices but intends to create resilient livelihoods, following a design process for regeneration and embodying a lifestyle in line with, or beyond, intergovernmental sustainability agendas. The aim of the following critical analysis is to assess the potential of PC and its practices in commercial agriculture.

Being grassroots in its origin, PC-related literature has mostly been written by teachers and practitioners for a mostly non-academic audience. This has maintained PC disconnected from scientific research (Ferguson and Lovell 2014). As a result, the analysis relies largely on non-academic assessments, which are complemented by a limited evidence base assignable to PC. Any peerreviewed literature on practices 'inspired by $\mathrm{PC}$ ' may be excluded inadvertently. Some authors prefer to publish without mention of the word 'permaculture', presumably to avoid a priori hostility towards a contended buzzword (Santos et al. 2018).

However, several initiatives have shown that PC has been evolving from its originally marginalised reputation as 'hippie gardening' to being mentioned by mainstream institutions as a beneficial concept and practice (Grayson 2010a). Within its framework designed to achieve land degradation neutrality for example, the United Nations Convention to Combat Desertification (UNCCD) lists 'permaculture' as an "activity to prevent land degradation" (Orr et al. 2017). The European Commission defines 'permaculture' as 'one of several prototypes of sustainable agro-ecology systems" within their Horizon 2020 research work programme 2016-2017 in relation to their research challenge on productivity gains through functional biodiversity and sustainable natural habitats (EU 2017).

The current paper thus intends to help identify the difference between visionary ideas, romanticising idealism and cult-like ideology (aspirations) on the one hand and viable solutions towards sustainability within the current European context (realities) on the other. This will be achieved by analysing PC and assessing its potential for development comparing a case study with (certified) organic agriculture (OA). We have chosen OA to compare PC because OA's practices are already established and considered to be closer to the intentions of $\mathrm{PC}$ than conventional farming practices.

The analysis comprises (1) a description of the idiosyncrasy of PC, (2) its underlying theory, (3) its ethics in relation to relevant policies, (4) the business case of a PC label and its relevance to sustainable farming and (5) potential additions of PC to current organic certification schemes.

\section{Permaculture}

PC has been criticised for its lack of a scientific foundation which is assumed to lead to unsubstantiated, overreaching or oversimplified claims. Although the number of graduate and postgraduate theses related to PC has been growing, thorough studies on PC's potential to mitigate or restore environmental and social damage in agriculture as well as business case studies are still scarce, such as, for example, the study on the economic performance of non-motorised 'biointensive organic micro-farming' in France (Fig. 1a, b) or the study on the livelihoods of diversified farming systems in the USA (Ferguson and Lovell 2014, 2017; Morel et al. 2016). PC's lack of connectedness with the mainstream - both weakness and strength - can be understood through the backgrounds and the intentions of its protagonists to distance themselves from modern, industrial agriculture.

Origins and early development in Australia

The term 'permaculture' is a portmanteau word invented by late Australian ecological visionary Bruce Charles 'Bill' Mollison (Mollison 1996; Dawborn and Smith 2011). It is composed of 'permanent' and 'agriculture', referring to an integrated system of eco-environmental design linked to the ideal of a predominantly perennial form of agriculture (Mercury 2016). Born in Tasmania, Mollison worked in his parents' bakery from age 15, followed by a job as mill worker and later-closer to nature - as seafarer, animal trapper and shark fisher before working in wildlife survey and for a fisheries commission. Mollison became a tutor at the University of Tasmania in 1968 and later a senior lecturer in Environmental Psychology (Grayson and Payne 2007; Bell 2016). 
The second name closely linked to the beginnings of PC is Mollison's student David Holmgren, born in 1955 in Western Australia. His parents were political activists; Holmgren had come to the Tasmanian College of Advanced Education to study Environmental Design in 1974, where he met Mollison and became his congenial partner.

In 1978, Mollison and Holmgren published their seminal book called "Permaculture One". In their introductory comment, Mollison and Holmgren (1978) state their vision: "[...] a pioneer effort [...] of perennial agriculture: the sort of system that will supply the essential needs of a city, a small settlement, or large family. It may well be unsuited to a large commercial enterprise, or inapplicable to conventional farming, but has greater relevance to those who wish to develop all, or part, of their environment to near self-sufficiency. [...]."

Mollison's and Holmgren's audience were Australians with no farming background who had acquired degraded land of low commercial value with the idea of developing an agriculture for self-sufficiency, whilst working off-farm on income-generating jobs. PC, as their designated "tool for urban and rural development", was intended to remedy the social challenges arising from increasing unemployment and early retirement (Mollison and Holmgren 1978).

Grayson (2010b) relates the subsequent success of Mollison's theoretical concept to what he calls a kind of social revolution driven by the awareness about the limits to growth, probably triggered by the energy crisis of the 1970s. Mollison's vision seemed to fit perfectly, being described at the time as "galvanizing" and "kindling one's imagination in a profound way", while Mollison himself was renowned for his "wit, provocative style and charisma". Reportedly, this lead to lifechanging impacts within his audience (Grayson and Payne 2007).

During the beginning of the PC movement in Australia, Mollison was "the dominant intellectual force in permaculture" forming its philosophical basis and disseminating it through meetings and courses, where "Bill's word became law. He was the authority" (Grayson 2010a). By 1981, Mollison's contribution to environmental design through PC had been honoured with the Right Livelihood Award (Bell 2016).

Mollison and Holmgren soon realised that "permanent agriculture' as a concept needed to be expanded to 'permanent culture', redefining PC as a design system beyond mere regenerative land use, extending into many more aspects of sustainable human lifestyle. (Holmgren 2002, 2011; Grayson 2010b).

Worldwide diffusion

The idea of PC started to spread beyond Australia, first within the Anglosphere and then, following translation of teaching material into other languages, around the rest of the world. To illustrate this 'geographical spread', the Australian Permaculture Research Institute and its Zaytuna Farm, arguably a leading PC demonstration and teaching site, list on their website a total of more than $2500 \mathrm{PC}$ inspired projects located all over the world. The type of projects regarded as PC can be demonstration sites, schools or other types of businesses and community projects defined as "generally landbased [...] with physical elements". In some cases, they include farms (PC Global 2017).

A survey conducted by the Permaculture Association UK in two phases during 2017 analysed the type of participants on PC educational courses, who are assumed to become drivers of PC inspired projects at some point. The non-representative views of 115 "experienced teachers" who were selected from around the world through personal networking, revealed that PC teachers dealt with "rather mixed audiences", drawn from a variety of sectors. A small number of those teachers stated their course audience was dominated by activists and community groups (IPEN 2017). This survey result is complemented by information derived from a total of 30 participants to PC farmer Sepp Holzer's course curriculum on the Krameterhof, Austria in 2010. It revealed that only one participant defined herself as 'farmer', two as professionals in landscaping and gardening while the others were from backgrounds mostly unrelated to farming or gardening, for example carpenter, pharmacist or financial advisor; three did not provide information as to their professional backgrounds (Dannenberg 2010, unpublished). Although these data may not be representative, they indicate that PC may attract people from many professions and not primarily from farming.

PC as eco-movement and as gardening practice may have remained within urban backyards, peri-urban allotments or rural homesteading, driven by privately organised educational workshops (Ferguson and Lovell 2014). However, PC has now probably gained a new momentum in parallel with 'peak oil', SDGs and 
climate change (Hopkins 2009; Veteto and Lockyer 2015; Henfrey and Penha-Lopes 2016; Kent 2016).

PC ethics

PC is characterised by a tripartite ethic. It was introduced by Holmgren (2002) as: (1) "Care for the Earth", (2) "Care for People", (3) "Set limits to consumption and reproduction, and redistribute surplus". The latter is often reduced to the shorthand "Fair Shares' (Burnett 2016).

\section{Care for the Earth}

Mollison and Holmgren (1978) had derived their philosophy of Earth Care (environmental integrity) partly from Taoism, "working with rather than against nature". PCs philosophy of environmental integrity has also found expression in domestic laws and legal action from "crime during peace time" within the concept of ecocide or Bolivia's "constitutional framework on mother earth and integrated development for good living". The legal framework gives equal priority to nature and to humans and intends to promote a life in harmony with Planet Earth; since its introduction, it has inspired other social movements and legislative initiatives in Ecuador, Argentina and Chile, amongst others (Gray 1996; ES 2010; Gudynas 2011; Morales Ayma 2012; Higgins et al. 2013). Holmgren links PC's Care for the Earth with four main topics: (1) living soil, (2) stewardship, (3) biodiversity and (4) sacredness of life, where he regards the current quality of soil as the best indicator for the health and well-being of humans in the future (Holmgren 2011).

\section{Care for people}

The second maxim, 'Care for People' (human integrity), places PC as a concept that is made for the benefit of human beings - not merely for nature conservation. This second ethical maxim also regards oneself as the entry point for change - Care for Self - by taking responsibility for one's personal situation rather than 'blaming others'. This connects with spiritual belief systems, such as, for example Buddhism, which teach their followers how to de-link one's emotional ups and downs from materialism and lead a balanced, more joyful life between the extremes of a self-destructive asceticism and rampant hedonism, by 'walking' the so called Middle Path of a life for the good of all beings (Nydahl 1999; Smith and Novak 2004).

\section{Fair shares}

Both Earth Care and People Care are interconnected and relate to the third ethics of 'Fair Shares'. The concept of Fair Shares was originally linked to the idea of "setting limits to consumption and reproduction and redistributing surplus" within a worldview where on the one hand there is abundance in nature but, on the other, there are also limits. Fair Shares can be regarded as an element of governance between the two former maxims, keeping a balance between what humans take from nature for their care and what nature requires for its own sake. It can be regarded as an ethic that ensures long-term social justice, wherein every living being, in addition to human beings, should be allowed to enjoy their integrity. See also chrematistics as 'art of acquiring money' vs. economics as 'art of housekeeping' (von Reden 2006).

Some economic experts argue that 'fair shares' cannot be attained within a monetary system that decouples money from its original intent to facilitate the exchange of goods and services. Therefore, PC practitioners often promote alternative economic maxims such as the "Economy for the Common Good" (Felber 2015) or the encouragement of local economic cycles through regional currencies (Hopkins 2009). Economic degrowth and putting limits to reproduction (population growth) are highly politicised topics and, remarkably, not represented in current SDGs.

\section{PC design principles}

PC prides itself on its 'design system' based on a series of principles - to a degree implicit in the early literature by Mollison and Holmgren (1978) and Mollison (1992). Subsequently, they have been structured and made more explicit by Holmgren (2011), establishing a design process for productive land termed 'settlement design' by Mollison (1992). The design concept is amongst others, based on a site or sector analysis describing the existing situation on a piece of land (status quo) combined with a 'zoning' process that gives spatial structure to the design of the productive system and, typically, leads to a base map drawing - a visual representation of the envisaged 
farming project (Fig. 1a, b). Such drawings are produced during courses that teach PC as part of its knowledge transfer system, also called 'permaculture design course' or PDC for short. The overall design process is typically headed by Holmgren's 12 principles: (1) observe and interact, (2) catch and store energy, (3) obtain a yield, (4) apply self-regulation and accept feedback, (5) use and value renewable resources and services, (6) produce no waste, (7) design from patterns to details, (8) integrate rather than segregate, (9) use small and slow solutions, (10) use edges and value the marginal and (12) creatively use and respond to change (Holmgren 2011).

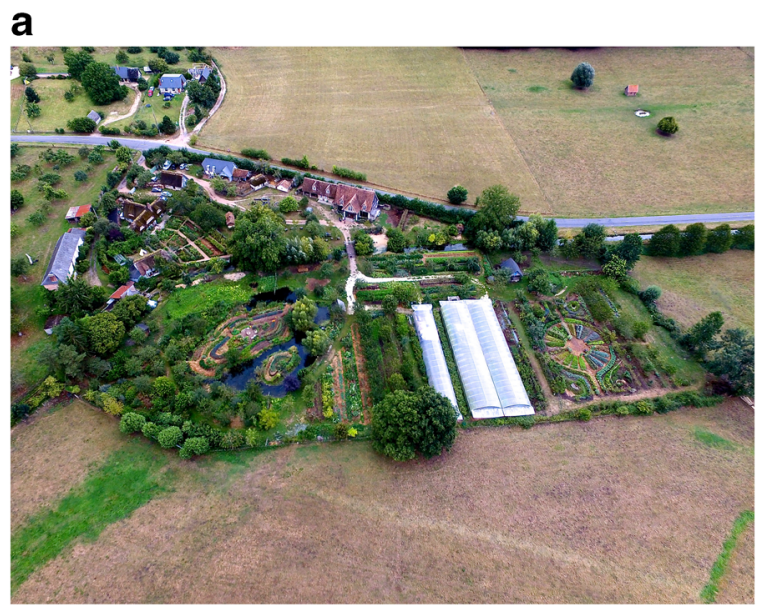

b

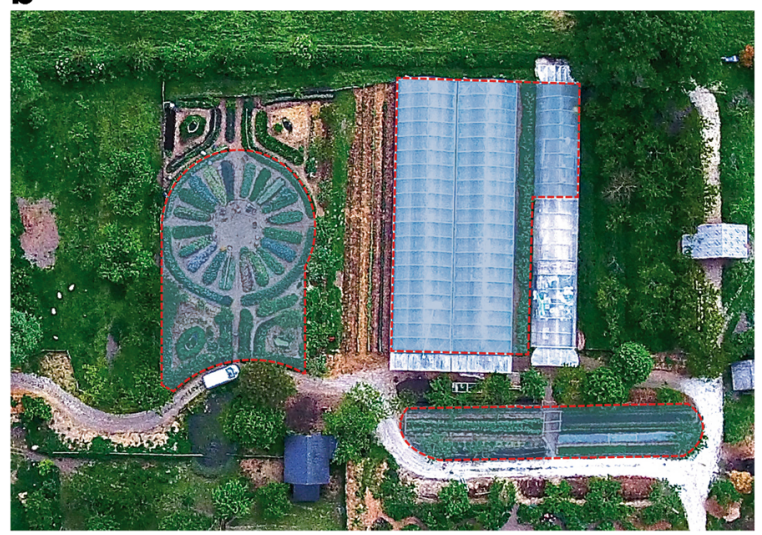

Fig. 1 a Ferme biologique du Bec, aerial view of the farm area constituting a PC inspired diversified farm. The farm owners describe their small scale farming as "done entirely by hand" and as "highly efficient and productive" (Bec Hellouin 2015; Ferme du Bec 2018). Photo: Ferme du Bec Hellouin. b Ferme biologique du Bec; red boundaries delimit the $1000-\mathrm{m}^{2}$ market garden study area that had been subject of an economic performance study showing economic viability. Photo: Ferme du Bec Hellouin
Detailed planning via visually enticing 'permaculture designs' (Fig. 2) may provide inspiration for the creation of a paradisiacal food producing landscape and motivate course participants to action as a starting point. Any project being implemented from this design and involving major financial investments should be backed by empirical or scientific evidence. This evidence should support agroecological functionality as well as financial planning to ensure economic viability and return on investment (Aranya 2012; Bec Hellouin 2015).

Site analysis and sector analysis: the site analysis entails the determination of natural variables, such as climate and microclimates, topographic structure, access to water, quality of soils, existing biotopes, including their fauna and flora, as well as cultural variables, such as ownership and physical access to land, existing services and infrastructure, amongst others. 'Sectors' refer to the flow of resources from outside the boundaries through the land with an effect on productivity, such as sun path, direction of winds or water flows; they are to be mapped in a drawing (Holmgren 2011).

'Zoning', as part of the actual PC design process, is required to optimise transport distances, thus reducing energy and time needed once the system is operational. It is typically visualised as a series of concentric circles, where the innermost circle is zone zero, followed by zones 1 to 5 . Holmgren defines zone 0 as the house or homestead, the starting and ending point of daily human activity. All subsequent zones are assigned in order of decreasing frequency of access for logistics, whilst zone 5 is left in its pristine state (Holmgren 2011). Some PC authors, especially those emphasising 'social permaculture', have added a zone 'double zero', defined as 'the self' (Macnamara and Storch 2012). PC's system of concentric circles reminds of the Thünen Rings developed by German agronomist, economist, social reformer and model farmer Johann Heinrich von Thünen (17831850). It was based on geo-economic location theory with the idea of creating a regional economy that takes into account transport costs (Wiskemann 1839). Traditional Mayan communities in Mexico have been designing their homesteads in a fashion similar to PC and might have been a key model inspiring early PC ideas (Mollison and Holmgren 1978; Flores et al. 2012). A zoning approach similar to PC has also been described for modern agroecological designs in tropical Latin America by Espinoza Alzate et al. (2011) for sustainable agricultural planning of agroforestry systems. Their innermost first circle represents a productive system 


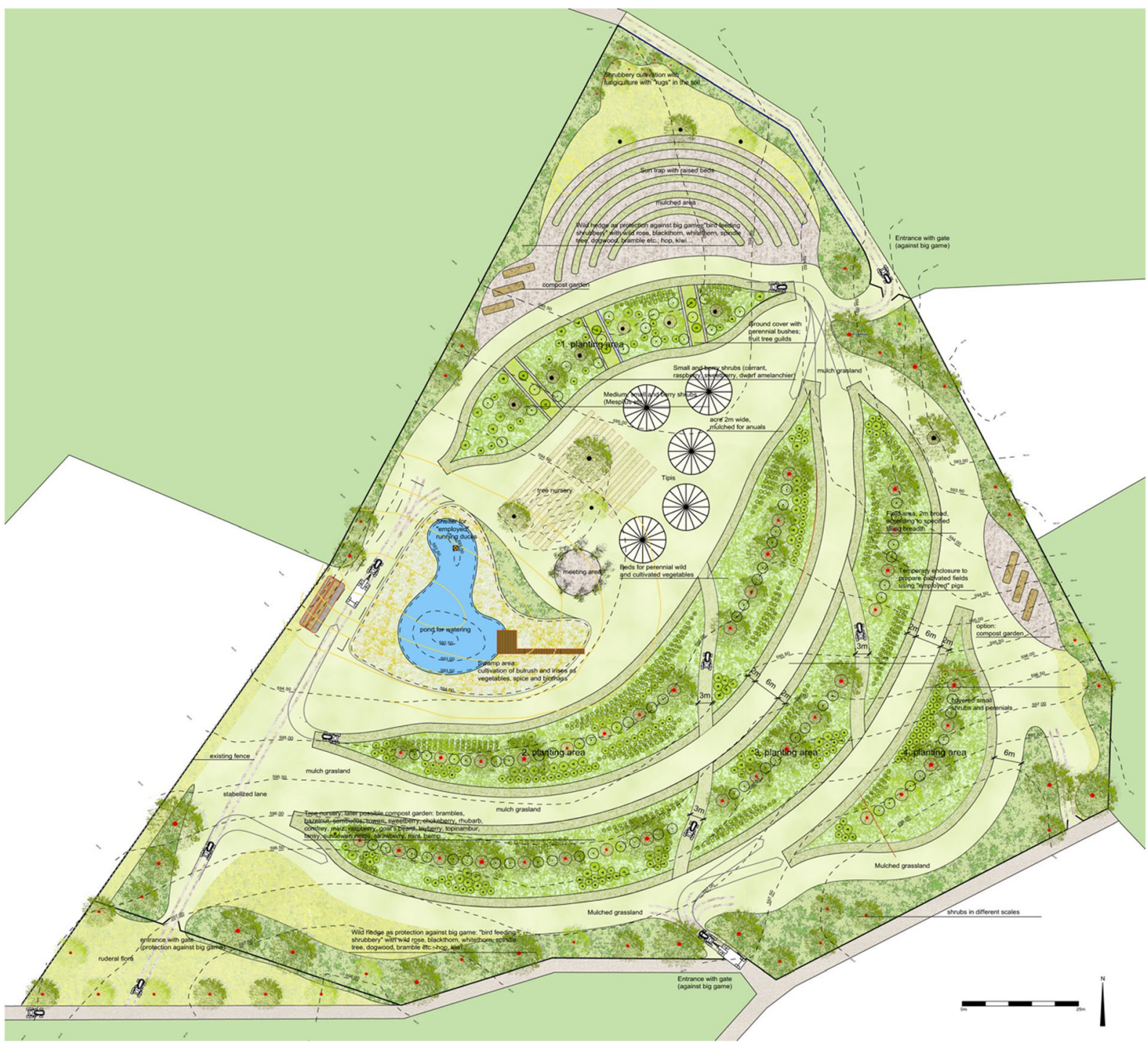

Fig. 2 Example of a typical PC design for a visionary productive landscape, in this case a conceptual design for communitysupported agriculture in Switzerland: PERMATUR Vision

placed within a farm (second circle). This agroecological structure is then placed within the wider environment that includes the economic, political and technological setting (third circle).

\section{Organic agriculture and its standards}

In contrast to PC-related produce, labelling of OA products was developed by organic associations very early on. For example, the German biodynamic farming association Demeter were already claiming trade mark
Birchhof. (http://www.permatur.org/vision-birchhof-english, 2018); photo: Matthias Brück

rights for their label in the 1950s in order to receive premium prices for their products (Vogt 2000). As the 'organic-ness' of a product is largely a credence quality which cannot be determined by either taste or laboratory analyses, detailed process standards are necessary to protect consumers and producers alike from fraudulent practices. Such standards were developed by the different European and US organic farming associations individually for their labels. Within this process, and for the first time in 1980, global guidelines for organic farming were defined in a participatory process by IFOAM (2014). 
Since 1991, Organic Agriculture (OA) has been included in the agri-environmental programmes of the European Union due to its positive impact on groundwater, biodiversity and soil quality. Hence, European organic farmers receive area-based subsidies for their farming practices which stimulated a further formalization and juridification of organic standards when the European (European Union) Regulation ECC 2092/91 came into effect. These standards were a blueprint for the Codex Alimentarius Guidelines (implemented in 1999) as well as for many other governmental and private regulations (Courville 2006). Today, governmental as well as private (association's) standards play an important role in the definition of organic farming practices, a feature that is so far not relevant for PC.

\section{Case study Lehmann/'real'}

In terms of agricultural practice, PC production standards or guidelines set by private enterprises are beginning to appear (e.g. Lehmann natur 2016a) but, to the best of the authors' knowledge, there is no legally binding standard such as exists for European Union OA (EC 2007) nor are there standards such as those set by organic or biodynamic associations or accredited boards of control linked to nationally and internationally recognised certification schemes (Bioland 2005; BDA 2012).

In 2015, the supermarket retail chain in Germany 'real-SB-Warenhaus GmbH' created a PC label for a series of fruits and vegetables offered seasonally and in limited quantities. 'Real' had defined their PC as "a particular form of organic farming with complementary aspects" (Verbraucher Initiative 2015) supported by an external advisory board as part of their Corporate Social Responsibility activities (real 2015). They collaborate with Lehmann natur $\mathrm{GmbH}$ as wholesale supplier which has in turn set up PC production criteria and an internal PC certification scheme to qualify farms as 'PC suppliers' (Lehmann natur 2016b).

The label 'real-Permakultur' raises questions, for example, around what is different about such labelled products when compared to EU organic certification or other organic certification labels (n.b.: the word 'real' is not intended as an adjective qualifying the label's PC as real vs. 'unreal' PC but incidentally relates to the name of the supermarket chain). Label Online (2017), a website with information and evaluations on product labels indicating quality in Germany, defines the real-
Permakultur label as "a label on products that already carry the EU certified organic logo or a German organic certification logo". In addition, real-Permakultur formulates "further criteria, including socio-cultural criteria, such as for example the surrounding cultural landscape of the farm and the company culture." The label can be considered a 'sustainability label' where "the aim of the concept of PC is a special form of OA with complementary aspects in near-natural ecosystems. Fruits and vegetables should be grown in harmony with nature" [translated (Label Online 2017)]. Those criteria that go beyond organic certification are defined as "[...] for example promoting the building of a humus layer, a sparing use of water, the conservation of biodiversity, nature and habitats".

The case of the real-Permakultur (rPC) label shall serve as a template to develop the arguments within the current paper. These may offer immediate practical benefits to help meeting SDGs in current farming. The review is mainly limited to the European context. Putting rPC into perspective with various existing regulatory frameworks and agendas will show room for improvement with regard to existing farming practices and possible benefits in terms of sustainability and regeneration at farm, landscape, biome or planetary level, pointing towards its potential for scaling out or up, and improving resilience.

The rPC principles as published by Lehmann natur (2016a) are intended to increase plant and animal biodiversity, protect soil and store water, improve soil fertility and protect the climate through carbon storage in commercial farming. The aim is to obtain stable as opposed to maximised yields, whilst relating this to resilience. The flavour of fruits should be strong and independence from agro-industry is advocated. Principles are divided into four parts: 'basic principle', 'soil protection \& build-up', 'cultivation' and 'water'. The basic principle requires certification of the farm according to EC 834/2007 (EC 2007) as a prerequisite for consumer safety while preference is given to private organic certification labels. In Table 1, a comparison of the Lehmann Natur guidelines for farms producing real-Permakultur products versus the IFOAM (IFOAM 2012) and Demeter standards (Demeter 2017) for organic produce is shown. The IFOAM (2014) norms were chosen because of IFOAM's claim as a "global organic umbrella organisation since 1972" to promote international conformity, its strategic plan towards 'Organic 3.0' (IFOAM 2018) and its holistic approach 
Table 1 Comparison of Lehmann Natur Guidelines for realPermakultur label [translated and adapted (Lehmann natur 2016b)] with IFOAM norms (IFOAM 2014) and Demeter Standard (Demeter 2017). Relevant terms (rPC) and their counterpart
(IFOAM, Demeter) are printed in bold. COROS: Common Objectives and Requirements of Organic Standards, IFOAM Standards Requirements. Bold type in citations set by authors to highlight differences

\begin{tabular}{lll}
\hline rPC Criteria & IFOAM & Demeter \\
\hline
\end{tabular}

\section{Basic criterion}

At least EU certified organic; private certificates of organic farmer's associations preferred; PC as internal certification by Third-Party Certification.

2 Soil protection/accumulation (specific practices)

2.1 If appropriate: Cultivation along contour lines, i.e. keyline design/terracing.

2.2 Detection (soil probe) and elimination of soil compaction by suitable measures, e.g. soil loosening and/or application of green manure, etc.

2.3 Gentle, minimum tillage, if possible no turning of soil; if sensible: raised mound (dam) cultures; Reduced soil compaction through e.g. wide tyres, reduction of axle load, etc.

2.4 Land cover by planting or growing local plants (wild herbs) and/or mulch where appropriate and not contraindicated by increasing pest populations
2.5 To increase the humus content in soil to soil and climate-dependent optimum values: use of compost and other organic fertilizers, if possible from own production or if possible regional purchase of raw materials
International accreditation body providing a good practice standard.

"[...] 2.2 Soil and Water Conservation [...] 2.2.2 [...] Such measures may include, but are not limited to: $[\ldots]$ contour ploughing $[\ldots]$ and other [...] practices that conserve soil. [...]".

Plant based ground cover and green manures recommended to maintain or increase soil fertility (refer to line 2.4 below in this table).

"[...] II. COROS [...] 1.2 [...] Organic crop production systems conserve or improve the soil's structure, organic matter, fertility and biodiversity. [...]".

"[...] 2.2 Soil and Water Conservation [...] 2.2.2 [...] Such measures may include, but are not limited to: [...] minimal tillage $[\ldots]$ and other $[\ldots]$ practices that conserve soil. [...]".

For mulching see section 2.5 of this table below. "[...] II. COROS [...] $1.2[\ldots]$ Organic crop production $[. .$. includes a diverse planting scheme [...]. For perennial crops, this includes plant-based ground cover. For annual crops, this includes diverse crop rotation practices, cover crops (green manures), intercropping or other diverse plant production with comparable achievements. [...]".

"[4.4 Soil Fertility and Fertilization General Principle [...] to increase o $\mathrm{r}$ at least maintain its fertility and biological activity [...]

Recommendation: [...] based on material $[. .$.$] , such as green$ manure, compost or mulch, obtained through the following sources $[\ldots]$ : a. organically produced on the farm; b. of organic quality, obtained from the surrounding farms or natural environment; [...]
Organic standard relevant to Third-Party Certification

Refer to line 2.4 below in this table.

"[... Special attention is paid to a
balanced build-up of humus
using $[\ldots]$ suitable tillage $[\ldots]$...

Organic mulching with decomposable materials used to improve soil fauna but not mandatory. Green manure with legume mix is important. One third of any crop rotation should be green manure. Fallow land requires a cover crop during the growing season, during winter all land should be green.

In fruit growing and viticulture the system must be appropriately covered year-round, with many different plant species that are not to be mowed or mulched before flowering.

"[...] Special attention is paid to a balanced balanced build-up of humus using compost and green manures $[\ldots]$ in horticulture, fruit growing and viticulture". 
Table 1 (continued)

\begin{tabular}{lll}
\hline rPC Criteria & IFOAM Demeter
\end{tabular}

3 Cultivation (specific practices)

3.1 Cultivation in mixed cultures/strip culture/agroforest systems with legumes, herbs, local growth of wild herbs (e.g. within dam culture in dam valleys) etc.

3.2 Usage of organic seeds and seedlings; recommendation: Focus on original, resistant, tasty, locally adapted varieties, if appropriate wild varieties, possibly own propagation. Exceptions are possible, depending on availability.

3.3 Increasing biodiversity through A. mixed, wide hedge elements to structure the landscape, if permitted or near-natural forest edges; B. biodiversity areas with local, insect-friendly plants C. creation of natural habitats; standposts, ponds, if sensible and possible

3.4 Beekeeping on farm or in cooperation with beekeepers and/or bumble bees, if appropriate, promotion of wild bees (e.g. flowering strips)

3.5 Application of compost teas, microorganisms, herbal extracts, etc. oils, homoeopathy, beneficial organisms etc. for support, if necessary [non-harmful application of nutrients and fertility products] should be evaluated through [...] indicators, such as [...] maintenance and increase in soil carbon content over time $[\ldots]$...

“[...] 4.5 Pest, Disease and Weed Management; General Principles [...] locally adapted rotations [...] functional biodiversity [...] Requirements: 4.5 .1 [...] appropriate rotation programs, intercropping and companion planting $[. .$.$] ".$

"[...] 4.8 Breeding of organic varieties $[. .$.$] not simply use$ or production of organic seeds from regular (conventional) varieties. [...] General principles [...] Organic varieties are obtained by an organic plant breeding program $[. .]$.$" ".$

"[...] 2.0 Organic Ecosystems, 2.1. Ecosystem Management [...] Requirements 2.1.1 [...] design and implement measures to maintain and improve landscape and enhance biodiversity quality, by maintaining on-farm wildlife refuge habitats or establishing them where none exist. Such habitats may include, but are not limited to: [...] hedges, hedgerows, edges between agriculture and forest land, groups of trees and/or bushes, and forest and woodland [...] ecologically diversified (extensive) field margins $[. .$.$] waterways,$ pools, springs, ditches, floodplains, wetlands, swamps and other water-rich areas $[. .$.$] areas \mathrm{w}$ ith ruderal flora $[. .$.$] ".$

Beekeeping best practices laid down but keeping bees is not required.

Compost application: see above, line 2.5 of this table. "Oils" as crop protectants and growth regulators in Appendix 3. "Appendix 2: Fertilizers and soil conditioners: [...] Plant preparations and extracts $[\ldots]$ Microbiological preparations based on naturally occurring organisms $[\ldots]$ Biodynamic preparations [...]".
Special attention is paid to the design of crop rotations in horticulture, fruit growing and agriculture.

Plant breeding should take place on Demeter certified land. Where not possible, it should be on organic certified land using Demeter procedures and preparations. Controls must be allowed giving access to the land.

Soil must not be without cover or natural greening during the entire year. The enterprise must show engagement with regard to care for biodiversity.

If biodiversity areas comprise less than $10 \%$ of the farm's land including adjacent land, a biodiversity plan must be defined and approved by the certification body. This plan may include measures of preservation of rare or endangered plant or animal species, promotion of bird and insect life through creation of habitats, utilisation of biodynamic plant or animal breeding.

Keeping bees is not a requirement. The management of bees itself however is regulated.

Soil adjuvants, soil vaccines, adjuvants for soil life according to Demeter requirements, e..g [...] microorganisms, grain ferment, rhizobia, mycorrhiza, microbial or plant based compost activators, extracts and preparations from plants. 
Table 1 (continued)

\begin{tabular}{|c|c|c|}
\hline rPC Criteria & IFOAM & Demeter \\
\hline \multicolumn{3}{|l|}{$\begin{array}{l}4 \text { Water (Specific practices related } \\
\text { to water consumption) }\end{array}$} \\
\hline $\begin{array}{l}\text { 4.1 Measures for water saving and } \\
\text { water collection, water retention } \\
\text { basin with waterproofing if } \\
\text { necessary }\end{array}$ & $\begin{array}{l}\text { “[... } 2.2 \text { Soil and Water } \\
\text { Conservation }[\ldots] \text { 2.2.6 [...] } \\
\text { not deplete nor excessively } \\
\text { exploit water resources, and } \\
\text { [...] seek to preserve water } \\
\text { quality. [...] where possible } \\
\text { recycle rainwater and monitor } \\
\text { water extraction }[\ldots] " .\end{array}$ & $\begin{array}{l}\text { The sustainable use of resources } \\
\text { including water is part of } \\
\text { the basic principles. No specific } \\
\text { practices nor required infrastructure } \\
\text { is laid down. }\end{array}$ \\
\hline
\end{tabular}

based on four principles: health, ecology, fairness and care. The German Demeter guidelines (Demeter 2017) were selected as organic certification standard from the Demeter parent organisation due to their claimed strictness going back to the path laid down by Rudolf Steiner in 1924. The guidelines envision a holistic approach based on Body, Mind and Soul and "humankind in balance with nature" (Demeter 2019). As members of the oldest organic association in Germany, they are assumed to contribute significantly more than what is laid down by the organic EU norm (EC 2007).

\section{Discussion}

PC label

Currently, consumers can choose from a wealth of food products with specific characteristics such as 'gluten free', 'lactose free' or 'GMO free', or from products with labellings indicating specific production features such as 'organic agriculture' (association labels or EU normative), or from 'integrated farming', or from products indicating provenance, such as 'regional'. The creation of a further label indicating 'permaculture' and the launch of the respective products represents yet another criterion that consumers can use to make a choice between products. With the increasing number of labels specifying features and farming alternatives, however, the consumer's ability and willingness to differentiate between multiple claims are likely to decrease. This in turn might lead to the average consumer ultimately choosing the cheaper option.

As shown above, PC is not a form of agriculture that emerges simply by applying its 12 principles but also a design tool for dealing with complex systems and for shaping a sustainable society on the basis of given ethical values. When analysing the PC principles with respect to their compliance with organic or biodynamic production standards, it is important to bear in mind that the 12 principles alone do not reflect the entire concept of PC. At the same time, PC does not mandatorily comply with the imperatives of OA. Actually, products labelled as from 'permaculture' might even fulfil fewer of the requirements set out by $\mathrm{OA}$.

\section{PC practice}

The low academic threshold of the PC approach often appeals to people who themselves have scarcely any experience in primary production. Additionally and as a result of increased urbanisation, permaculturists may not have developed a relationship with cultivation and nature. It is experienced as something 'learnt' rather than 'lived', potentially leading to inappropriate simplifications. With little reliable data to support the PC production systems, permaculturists may often trust individual reports, some from other contexts (Ferguson and Lovell 2014; Fiebrig and van de Wiel 2017). For newcomers to farming, this may lead to risks in economic viability and produce quality. This being said, aspects that might be considered innovative in PC can actually be part of the basics of gardening and farming as practised two or more generations ago and, as such, they can be considered part of general knowledge. In summary, PC can be seen as a tool to revert to traditional practices whilst developing new practices and technologies that can be incorporated into current gardening and agriculture. 
Once PC enters the agricultural business sector, it requires the restructuring of farms into complex polycultures, where planning does become challenging. The majority of existing planning and support resources for commercial farming are still focused on simple, nondiversified farms (World Bank 2006). Farmers and businesses that adopt the PC approach are at the same time likely to face significant barriers to achieving economic viability. Similarly, other alternative agricultural practices such as agroforestry face political and practical acceptance barriers in establishing themselves within the predominant system. In order to make PC acceptable and respectable, consistent codes of practice must be established for specific and essential aspects so as to avoid setbacks in food safety and public confidence. While there should be no doubt about the considerable social engagement PC has stimulated within communal gardening practices and community supported agriculture (CSA) worldwide, the question remains if PC can gain recognition amongst consumers who trust the proven and well established concepts of OA but who do not have the leisure time, energy and money at their disposal, or simply do not wish, to participate in gardening activities and related CSA.

Face-to-face interaction on the one hand is necessary for the creation of trust and appreciation. Thus, direct marketing and CSA are distribution channels often favoured by PC. On the other hand, this argumentation seems to deny the PC label's right to exist for products that are neither regional nor seasonal. The question arises as to how an agricultural enterprise can pursue the visionary goals of PC and at the same not fail within the current economic system.

PC case study Lehmann/'real'

We analysed the Lehmann Natur Guidelines for realPermakultur (rPC), translated and adapted from Lehmann natur (Lehmann natur 2016b), with International Federation of Organic Agriculture Movements Norms including COROS (IFOAM 2014) and Demeter Standard (Demeter 2017) for organic produce listed in Table 1.

rPC Criterion 1 requires EU organic certification as minimum to ensure consumer safety and prefers farms subject to certification schemes from private associations such as Demeter, deemed to extend beyond minimum EU requirements. An independent rPC advisory board consisting of three representatives-from consumer protection, nature conservation and agroecology science respectively - and an external certifying body are claimed to ensure transparency and reliability.

rPC Criterion 2.1 "Cultivation according to contour lines (keyline design/terracing)" refers to the Keyline Design System developed by the engineer Percival Alfred Yeomans (1904-1984) in Australia. In many parts of this continent, water management is a crucial factor for the success of agriculture. Keyline Design (KD) is an approach that requires close attention to the topography of land and the flow of water, especially during rainfall. It involves the installation of water collection at strategic points in the terrain (reservoirs: so-called key points) as well as gravity-driven irrigation systems emanating from them. Other elements of KD are earth channels ('swales') to guide water from rainfall towards the drier slopes within a hilly landscape, thus improving overall water infiltration. KD aims at improving water use efficiency from rainfall by decompaction of soil, improved infiltration and reduced erosion and in the long run at building up top soil and soil biodiversity (Yeomans 1958; Yeomans and Yeomans 2002). Although keyline design is an intricate method widely advocated by PC practitioners and in line with other methods of regenerative agriculture (Widdowson 1987; Savory and Duncan 2016), the system is not yet backed by sufficient experience in Europe and may be an interesting field of research, particularly within the dryer climates of the Mediterranean climate zones. While IFOAM (2014) mentions contour ploughing as one of the soil and water conserving methods, Demeter (2017) shows no specific practice as an equivalent. A cultivation 'design along contour lines' such as KD or terracing goes clearly beyond current requirements and is expected to benefit soil and water conservation.

rPC Criterion 2.2. "Detection (soil probe) and elimination of soil compaction by suitable measures [...]" is not explicitly mentioned by IFOAM (2014) nor Demeter (2017) but organic production systems generally have to employ measures to prevent soil degradation and improve soil structure. It seems sensible to establish a regeneration monitoring of soil structure and humus content as a measure of ongoing process quality management.

rPC Criterion 2.3 "Gentle, minimal tillage, if possible no turning of soil [...]" is not explicitly found within the other two aforementioned frameworks even though their provisions probably have a positive impact on the prevention of soil erosion (van Pelt et al. 2017), promotion of soil fertility (Nunes et al. 2018) and water resource consumption. 
Conservation tillage, with some pioneer experience also in organic farming (Zikeli and Gruber 2017), is an approach to save soil water in arid and semi-arid areas, though not yet widely used on farms in humid, temperate climates. The benefit of 'Turiel' ridged or mound cultivation (Damm culture) developed in arid and semi arid areas is still discussed controversially for organic farming in Europe but may have some benefits regarding water conservation (Mäder and Berner 2012).

An important aspect of PC is the judicious use of resources. Therefore, preference is to be given to methods that use resources efficiently as well as promoting closed cycle management with multiple uses (one element for various functions and one function by various elements). This is reflected in $\mathrm{rPC}$ criteria 2.3 and 4.1 (Table 1) which explicitly refer to water and soil. Within the standards of reference (IFOAM and Demeter), water and soil are also mentioned as important resources without naming specific techniques other than 'minimal tillage' or 'suitable tillage', respectively.

rPC Criterion 2.4 "Land cover by planting or growing local plants (wild herbs) and/or mulch" is comparable to the other two standards of reference where usages of plant-based ground (perennial plants) and cover crops are mandatory; however, there is no explicit focus on local plants. Local flora might be of benefit as it would provide potentially more suitable habitats for local fauna and thus promote populations of endangered species.

rPC Criterion 2.5 "To increase the humus content in soil to soil-dependent and climate-dependent optimum values: use of compost and other organic fertilizers" is equivalent with the standards of reference where the increase of soil fertility only through animal manures, other biodegradable inputs and/or by nitrogen fixation from plants, naturally occurring mineral fertilizers are allowed as supplements. rPC's focus on closed cycles mentions explicitly that these inputs must be produced on farm or be obtained from regional sources to prevent 'grey energy' consumption.

"Cultivation in mixed cultures/strip culture/ agroforest systems" mentioned under rPC Criterion 3.1 is covered by IFOAM with reference to the need for functional biodiversity, specifically through rotation programmes, intercropping and companion planting. Demeter is only laying down the general need of crop rotations in horticulture, fruit growing and agriculture. Again, same as under Criterion 2.4, rPC promotes wild herbs, the standards of reference do not; $\mathrm{rPC}$ requires mixed farms with 'polycultures' while typical monocultures must provide other measures to ensure on-farm biodiversity.

rPC Criterion 3.2 "Usage of organic seeds and seedlings" promotes tasty, locally adapted varieties which may not only make more economic sense than the use of highperformance varieties, especially for regional markets, but may also be ecologically more valuable because they contribute to the preservation of global genetic diversity. It could be considered a change of focus on long-term yield stability rather than short-term profit maximisation.

rPC Criterion 3.3 and proposed measures for "Increasing biodiversity" through habitat creation is in close agreement with IFOAM except for the inclusion of standposts and ponds as wet habitat provision for rPC. Demeter is more general regarding habitat creation on a minimum of $10 \%$ of farm land or immediately adjacent land, this includes biodynamic plant or animal breeding.

rPC Criterion 3.4 "Beekeeping" promotes bees including wild bees and other pollinators together with habitat creation under Criterion 3.3 and can also be considered an important issue for society as a whole against the background of declining insect populations (Hallmann et al. 2017); within the standards of reference keeping of bees is not mandatory but desirable to promote insect diversity and ideally obviating the need for synthetic pesticides. rPC Criterion 3.5 "Application of compost teas [...]" is in accordance with both standards of reference.

rPC Criterion 4.1 "Measures for water saving and water collection [...]" is mapped closely by IFOAM with the addition of mentioning water retention basins. Such basins may play an increasing role in water and soil retention on the land during extreme rainfall events, improve water infiltration and ground water recharge and in creating wetland habitats (Fiebrig and van de Wiel 2017).

PC within OA: ignore it, adapt it or adopt it?

The present contrasting juxtaposition of OA and PC shows that their concepts and practices are in essence compatible. Most of the aims of (agricultural) PC are, indeed, congruent with the ambitions and intentions of OA. As opposed to PC, OA follows clear rules and regulations that allow for upscaling and replication. They are comprehensible to the consumer. Many aspects of PC in turn are not regulated, such as the management of animal husbandry or the use of plant 
protection products, e.g. copper products or neem oil and related maximum limits. Upscaling in a commercial setting is not at its heart. PC could be seen as a somehow weaker, 'fuzzier' concept, as opposed to a specific action plan able to give the consumer clear information about the production method of their food and related environmental impacts. Notably, producers in PC are often newcomers to agriculture or amateurish gardeners who may lack professional qualification for the production of food.

$\mathrm{OA}$ as a practice has taken many years to move beyond its own little world of esoterism and idealism and for its research to become recognised as a sound science. In fact, comparative research between $\mathrm{OA}$ and conventional agriculture has become unnecessary: it is well established how, for instance, crop yield or ecosystem services differ from one another and generally there remains no doubt that OA is essentially 'good'. A consistent scientific approach in OA research has thus long become standard. This has lead to both the scientific community and political decision makers respecting the results.

Regarding PC, published scientific approaches are scarce and publications tend to be popular, based on empirical research from authors who are often not independent in the scientific sense. It remains debatable whether or not OA can receive a new momentum from PC. This should satisfy the current search for something 'new' and 'beyond' to mitigate climate change and adapt to it. Additionally, it may restore landscapes and natural resources such as, e.g. soil, nutrients, water and biodiversity and not least, reconcile conflict-torn societies. Whether commercial PC is at all possible without OA standards needs to be discussed openly with consumers who expect a safe product, whose origin and production methods are clearly known. So long as there are no consistent and binding standards for PC, its practice in commercial settings will remain at least controversial.

PC aspirations vs. realities

From a practical viewpoint, PC can be a comprehensive framework for planning, designing and building human settlements including farms in a fashion that is more sustainable and ethical. It could help to better balance out interests of individual financial gain - related to the aforementioned chrematistics - against the general needs of land, fauna, flora and humans.
Claims as to the productivity of PC systems should be based on robust experimental data and not merely on anecdotal evidence blended with vested interests of PC teachers and project consultants. PC is inspiring per se, and this may be due to our innate desire to live in an environment that is close to quasi-paradisiacal ideas ('Garden Eden'), possibly related to our ancestral desire to live as hunter-gatherers in a mostly unaffected natural environment rich in biodiversity. Peer-reviewed scientific evidence, case studies based on empirical knowledge as well as actual business-case data and best-practice guidelines should avoid mis-investments driven by unsubstantiated claims and overenthusiasm. A judicious redesign of farming systems using a mindful PC approach may improve overall sustainability, promote regeneration and increase resilience through better soil management as well as increased water availability and biodiversity.

From a historical viewpoint, it could be claimed that developments in general do not tend to happen continuously but more in a fashion of leaps and bounds. Rudolf Steiner's ideas of a holistic system inspired agriculture in 1927. The concepts were taken forward by Howard and Balfour in the 1940s and other practitioners later on. This overall ecological development is now probably receiving a new impulse towards a different direction by the ideas of PC. While PC was developed in Australia to address specific conditions such as long periods of drought, the growing challenges for agriculture also in humid and temperate climates due to extreme weather events might call for PC concepts to improve resilience, thus becoming part of the global adaptation strategy.

We propose several aspects to be developed within the context of PC in commercial farming systems: (1) any product carrying 'permaculture' as part of its labelling should comply at least with organic certification standards; (2) viable recommendations for regenerative and restorative PC practices should be established, such as soil, wind and water management including the integration of livestock, matching with geology, pedology, topography and climate zone; (3) business case figures should be gathered to establish economic viabilities short and long term; (4) an ecologic footprint balance should be determined for each product showing a reduction in the use of external inputs and concomitant transport routes; (5) an accounting for waste and waste streams and the impacts of packaging material should be established including nutrient cycling from livestock and where possible human excreta; (6) a human well- 
being balance should promote high social standards along the ideas of an 'Economy for the Common Good' (e.g. Blachfellner et al. 2017).

There is little doubt about PC's potential for improving eco-literacy as well as for promoting social integration and well-being in near-natural environments (Lockyer and Veteto 2015). PC may, however, still have to show its potential in providing viable agroecological business models and additional ecosystem services at landscape level. Trustworthy data is needed, unless practitioners limit themselves to urban or periurban hobby and lifestyle gardening.

Introducing a PC design approach to commercial farms faces the challenge of changing infrastructure, single practices and entire processes while the enterprise needs to remain not only operational but also profitable. A farm redesign guided by mindful observation and reflection may in turn guide adaptation towards increasing resilience at farm and landscape level, i.e. by reducing soil erosion and the need for external inputs as well as by increasing biodiversity.

\section{Conclusions}

PC as a comprehensive sustainability concept and a gardening practice could be the entry point for engagement with a wider group of professionals - not only farmers - creating consumer awareness in response to environmental crises in general and to food crises in particular. In practice, PC farms - with an inherent tendency towards smaller scale - could become biodiversity hubs, experimental centres and demonstration sites for large scale landscape and community restoration, in conjunction with academic partners.

We propose combining the prescriptiveness of a process standard, such as certified OA, with the concept of PC. The latter provides a complementary framework facilitating both a deductive and an inductive design approach (Lepper 2016) with an increased focus on restoration of the resources: soil, water and biodiversity. It may add the flexibility needed for redesign towards increased resilience and improve farming systems in terms of ecologic, economic and social outcomes. Once gains in ecosystem services and reductions in resource consumption by PC are quantifiable, they need to be valued by society and must receive compensation. This would make regeneration economically viable- - not only for existing businesses (short-termed) but for generations to come.

Acknowledgements To Charles Hervé-Gruyer for photographic material about Ferme du Bec Hellouin, Normandie, France; to Matthias Brück for an exemplary PC design; to Sabine Baur for complementary graphic work; to Marion Buley, Andrea O'Brien, Monica Brown and Mark Tilzey for proof-reading the manuscript.

Funding information The Centre for Agroecology, Water and Resilience of Coventry University, UK provided generous financial support towards permaculture related research.

\section{Compliance with ethical standards}

Conflict of interest The authors declare no conflict of interest. Immo Fiebrig is member of the independent 'real' PC advisory board, but received no financial or any other type of remuneration for this publication.

Open Access This article is licensed under a Creative Commons Attribution 4.0 International License, which permits use, sharing, adaptation, distribution and reproduction in any medium or format, as long as you give appropriate credit to the original author(s) and the source, provide a link to the Creative Commons licence, and indicate if changes were made. The images or other third party material in this article are included in the article's Creative Commons licence, unless indicated otherwise in a credit line to the material. If material is not included in the article's Creative Commons licence and your intended use is not permitted by statutory regulation or exceeds the permitted use, you will need to obtain permission directly from the copyright holder. To view a copy of this licence, visit http://creativecommons.org/licenses/by/4.0/.

\section{References}

Aranya (2012) Permaculture design. A step-by-step guide. Permanent Publications, East Meon

BDA (2012) Biodynamic association certification. Demeter and organic production standards. Stroud

Bec Hellouin (2015) Permacultural organic market gardening and economic performance, France

Bell G (2016) Bruce Charles 'Bill' Mollison 1928-2016. https://www.permaculture.co.uk/news/14748871427497 /bruce-charles-bill-mollison-1928-2016. Accessed 22 December 2017

Bioland (2005) Bioland standards 24. April 2005. http://organicrules.org/611/1/BIOLAND_production_ standards_2005_April_en.pdf. Accessed 4 January 2018

Blachfellner M, Drosg-Plöckinger A, Fieber S, Hofielen G, Knakrügge L, Kofranek M, Koloo S, Loy C, Rüther C, Sennes D, Sörgel R, Teriete M (2017) Economy for the common good: an economic model for the future 
Burnett G (2016) Permaculture: a beginner's guide. Spiralseed, Westcliff On Sea

Courville S (2006) Organic standards and certification. In: Kristiansen P, Taji A, Raganold J (eds) Organic agriculture a global perspective. CSIRO Publishing, Collingwood, pp 201-206

Dannenberg U (2010) Holzersche Permakultur-PraktikerAusbildung 2010. Krameter-Hof, Lungau

Dawborn K, Smith C (eds) (2011) Permaculture pioneers. Mellidora, Hepburn, Victoria

Demeter (2017) Production standards for the use of Demeter, Biodynamic $\AA$ and related trademarks, as at June 2017. https://www.demeter.de/sites/default/files/di production_stds_ demeter_biodynamic_17-e.pdf. Accessed 5 January 2018

Demeter (2019) Demeter eingetragender Verein. https://www. demeter.de/biodynamisches. Accessed 3 June 2019

EC (2007) Council Regulation (EC) No 834/2007 of 28 June 2007 on organic production and labelling of organic products and repealing Regulation (EEC) No 2092/91. OJ:1-23

ES (2010) Vivir Bien" propuesta del modelo de gobierno en Bolivia. https://www.economiasolidaria.org/noticias/vivirbien-propuesta-de-modelo-de-gobierno-en-bolivia. Accessed 8 January 2018

Espinoza Alzate JA, Rios LA, Zapata Tamayo MA (2011) Los Diseños Agroecológicos. Una herramienta para la planeación agrícola sostenible, Medellín

EU (2017) Horizon 2020. Work programme 2016-2017. Food security, sustainable agriculture and forestry, marine and maritime and inland water research and the bioeconomy

FAO, IFAD, UNICEF, WFP, WHO (2017) The state of food security and nutrition in the world 2017. Building resilience for peace and food security. http://www.fao.org/3/a-I7695e. pdf. Accessed 17 December 2017

Felber C (2015) Change everything. Creating an economy for the common good, 1st edn. Zed Books, London

Ferguson RS, Lovell ST (2014) Permaculture for agroecology. Design, movement, practice, and worldview. A review. Agron Sustain Dev 34:251-274. https://doi.org/10.1007 /s13593-013-0181-6

Ferguson RS, Lovell ST (2017) Livelihoods and production diversity on U.S. permaculture farms. Agroecol Sustain Food Syst 41:588-613. https://doi.org/10.1080 /21683565.2017.1320349

Ferme du Bec (2018) La métode de la ferme du Bec Hellouin. https://www.fermedubec.com/english/. Accessed 17 October 2018

Fiebrig I, van de Wiel M (2017) Evaluating the potential of surface water retention ponds for improving ecosystem services: a case study on a holding in southern Spain. https://www. researchgate.net/publication/316998601_Evaluating_the potential_of_surface_water_retention_ponds_for_ improving_ecosystem_services_a_case_study_on_a holding_in_southern_Spain/link/591d $29 \mathrm{da0}$ f7e $9 \mathrm{~b} 64281 \overline{4}$ c78a/download. Accessed 18 December 2019

Flores SF, Vermont Ricalde RM, Kantún Balam JM (2012) Componentes del huerto familiar del área Maya de la Península de Yucatán., Universidad Autónoma de Yucatán

Gray MA (1996) The international crime of ecocide. Calif West Int Law J:215-271

Grayson R (2010a) The Permaculture Papers - 1: Introductory notes. https://pacific-edge.info/2010/10 /permaculturepapers_introductory_notes/. Accessed 14 November 2018

Grayson R (2010b) The Permaculture Papers - 2: The dawn. https://pacific-edge.info/2010/10/the-permaculture-papers-2the-dawn/. Accessed 14 November 2017

Grayson R, Payne S (2007) Tasmanian roots. https://newint. org/features/2007/07/01/history. Accessed 18 December 2017

Gudynas E (2011) Buen Vivir. Today's tomorrow. Development 54:441-447. https://doi.org/10.1057/dev.2011.86

Hallmann CA, Sorg M, Jongejans E, Siepel H, Hofland N, Schwan H, Stenmans W, Müller A, Sumser H, Hörren T, Goulson D, de Kroon H (2017) More than 75 percent decline over 27 years in total flying insect biomass in protected areas. PLoS One 12:e0185809. https://doi.org/10.1371/journal. pone.0185809

Henfrey T, Penha-Lopes G (2016) Permaculture and climate change adaptation. Inspiring ecological, social, economic and cultural responses for resilience and transformation. Permanent publications, Hampshire, United Kingdom

Higgins P, Short D, South N (2013) Protecting the planet: a proposal for a law of ecocide. Crime Law Soc Chang:251-266

Holmgren D (2002) Permaculture. Principles and pathways beyond sustainability. Holmgren Design Services, Hepburn

Holmgren D (2011) Permaculture. Permanent Publications, East Meon

Hopkins R (2009) The transition handbook. From oil dependency to local resilience. Green Books, Totnes

IFOAM (2012) Organic without boundaries. https://ifoampublications/docs/organic_without boundaries_-_ifoam_celebrating. Accessed 14 July 2018

IFOAM (2014) IFOAM for organic production and processing, version July 2014, Bonn

IFOAM (2018) IFOAM Organics International. https://www. ifoam.bio/en/what-we-do. Accessed 3 June 2018

IPEN (2017) International survey of permaculture education, London

Kent R (2016) Flood and drought prevention and disaster mitigation: combating land degradation with an integrated natural systems strategy. In: Chabay IFM, Helgeson J (eds) . Land Restoration. Reclaiming landscapes for a sustainable future. Academic Press, London, pp 133-162

Label Online (2017) real-Permakultur private label. https://labelonline.de/label/real-permakultur/?cHash $=1 \mathrm{cf} 4751$ f92036913334971 d982fc27df\&type $=1487504640$. Accessed 19 December 2017

Lal R (2016) Feeding 11 billion on 0.5 billion hectare of area under cereal crops. Food Energy Secur 5:239-251. https://doi. org/10.1002/fes3.99

Lehmann natur (2016a) Permakultur. Auf dem Weg zu einer besseren Landwirtschaft. http://www.lehmann-natur. com/permakultur/. Accessed 15 December 2017

Lehmann natur (2016b) Permakultur Produktionsgrundlagen. http://www.lehmann-natur.com/fileadmin/user upload/FINAL_lehmann_Produktionsgrundlagen_DT_09_2016.pdf. Accessed 4 January 2018

Lepper $\bar{S}$ (2016) Bewertung eines Permakulturdesingns als Planungsstrategie für die nachhaltige Verbesserung von Ökosystemleistungen. Master Thesis, Technische Universität Braunschweig 
Lockyer J, Veteto JR (eds) (2015) Environmental anthropology engaging Ecotopia. Bioregionalism, permaculture, and Ecovillages. Berghahn, New York, Oxford

Macnamara L, Storch R (2012) People \& permaculture. Caring and designing for ourselves, each other and the planet. Permanent Publ, East Meon

Mäder P, Berner A (2012) Development of reduced tillage systems in organic farming in Europe. Renew Agric Food Syst 27:711. https://doi.org/10.1017/S1742170511000470

Mercury (2016) Bill Mollison, co-founder of global permaculture movement, dies in Hobart. http://www.themercury.com. $\mathrm{au} /$ news/tasmania/bill-mollison-cofounder-of-globalpermaculture-movement-dies-in-hobart/news-story/503c4e606 dc80d79936e1834618b19bd. Accessed 17 November 2017

Mollison BC (1992) Permaculture. A designers' manual. Tagari Publ, Tyalgum

Mollison BC (1996) Travels in dreams. Tagari Publications, Tyalgum

Mollison BC, Holmgren D (1978) Permaculture, Ealing

Morales Ayma E (2012) Bolivia: Ley Marco de la Madre Tierra y Desarrollo Integral para Vivir Bien, 15 de octubre de 2012

Morel K, Guégan C, Léger FG (2016) Can an organic market garden based on holistic thinking be viable without motorization? The case of a permaculture farm. Acta Hortic:343346. https://doi.org/10.17660/ActaHortic.2016.1137.47

Nunes MR, van Es HM, Schindelbeck R, Ristow AJ, Ryan M (2018) No-till and cropping system diversification improve soil health and crop yield. Geoderma 328:30-43. https://doi. org/10.1016/j.geoderma.2018.04.031

Nydahl LO (1999) Entering the diamond way. Tibetan Buddhism meets the west. Blue Dolphin, Nevada City

Orr BJ, Cowie AL, Castillo Sanchez VM, Chasek P, Crossman ND, Erlewein A, Louwagie G, Maron M, Metternicht GI, Minelli S, Tengberg AE, Walter S, Welton S (2017) Scientific conceptual framework for land degradation neutrality. A Report of the Science-Policy Interface, Bonn

PC Global (2017) Worldwide Permaculture Projects. www. permacultureglobal.org. Accessed 22 December 2017

real (2015) real,- PERMAKULTUR 100\% Natur. https://www. real.de/unternehmen/unternehmensveran twortung/sortiment/permakultur-100-natur/. Accessed 15 December 2017

Santos AP, Godinho D, Vizinho A, Alves F, Pinho P, Penha-Lopes G, Branquinho C (2018) Artificial lakes as a climate change adaptation strategy in drylands. Evaluating the trade-off on non-target ecosystem services. Mitig Adapt Strateg Glob Chang 23:887-906. https://doi.org/10.1007/s11027-0179764-x

Savory A, Duncan T (2016) Regenerating agriculture to sustain civilization. In: Land Restoration. Elsevier, pp 289-309

Smith H, Novak P (2004) Buddhism. A concise introduction, 1st edn. Harper Collins, New York
UN The General Assembly (2018) A/RES/70/1. Transforming our world: the 2030 Agenda for Sustainable Development. http://www.un.org/ga/search/view_doc.asp?symbol= A/RES/70/1\&Lang=E. Accessed 22 October 2017

Urwin K, Jordan A (2008) Does public policy support or undermine climate change adaptation? Exploring policy interplay across different scales of governance. Glob Environ Chang 18:180-191. https://doi.org/10.1016/j. gloenvcha.2007.08.002

van Pelt RS, Hushmurodov SX, Baumhardt RL, Chappell A, Nearing MA, Polyakov VO, Strack JE (2017) The reduction of partitioned wind and water erosion by conservation agriculture. Catena 148:160-167. https://doi.org/10.1016/j. catena.2016.07.004

Verbraucher Initiative (2015) Themenheft Verbraucher konkret 'Permakultur'. http://www.shared.real.de/markt/aktionen ohne_kw/permakultur/Themenheft_Permakultur_ Verbraucher_Initiative.pdf. Accessed 15 December 2017

Veteto JR, Lockyer J (2015) Environmental anthropology engaging permaculture. Moving theory and practice toward sustainability. In: Lockyer J, Veteto JR (eds) Environmental anthropology engaging Ecotopia. Bioregionalism, Permaculture, and Ecovillages. Berghahn, New York, pp 95-112

Vogt G (2000) Entstehung und Entwicklung des ökologischen Landbaus im deutschsprachigen Raum. Stiftung Ökologie und Landbau, Bad Dürkheim

von Reden S (2006) Chrematistike. In: Cancik H, Schneider H (eds) Brill's New Pauly

Widdowson RW (1987) Towards holistic agriculture. A Scientific Approach. Elsevier Science, Burlington

Wiskemann H (1839) Die antike Landwirtschaft und das von Thünen'sche Gesetz. Aus den alten Schriftstellern dargelegt. S. Hirzel, Leipzig

World Bank (2006) Global - international assessment of agricultural science and Technology for Development (IAASTD) project (English). World Bank, Washington D.C

Yeomans PA (1958) The challenge of landscape: the development and practice of keyline. Keyline Publishing PTY. V, Sydney

Yeomans KB, Yeomans PA (2002) Water for every farm. Yeomans keyline plan. Keyline Designs, Southport, Qld

Zikeli S, Gruber S (2017) Reduced tillage and no-till in organic farming systems, Germany - status quo, potentials and challenges. Agriculture 7:35. https://doi.org/10.3390 /agriculture 7040035

Publisher's note Springer Nature remains neutral with regard to jurisdictional claims in published maps and institutional affiliations. 